\title{
MID-TERM MODIFICATION OF TERMS AND CONDITIONS OF EMPLOYMENT
}

The collective bargaining agreement between the employer and the representative of his employees promotes a primary purpose of national labor policy-that the employer and employees stabilize their respective rights, duties and benefits for a specific period of time, thereby furthering the efficient and orderly conduct of interstate commerce.' The degree of stability achieved by the contract and the corresponding degree of flexibility left to the parties are determined by statutory guidelines and specific clauses which may be included in the collective bargaining agreement. This Note will analyze the interplay between the statute and available contractual "tools" and the effect of such statutory and contractual provisions upon "mid-term modifications"-changes in the terms and conditions of employment during the existence of a collective bargaining agreement. ${ }^{2}$ The statutory and contractual components which will be discussed are section

1. It is declared to be the policy of the United States to eliminate the causes of certain substantial obstructions to the free flow of commerce and to mitigate and eliminate these obstructions when they have occurred by encouraging the practice and procedure of collective bargaining and by protecting the exercise by workers of full freedom of association, self-organization, and designation of representatives of their own choosing for the purpose of negotiating the terms and conditions of their employment or other mutual aid or protection. Labor-Management Relations Act, 29 U.S.C. $\$ 151$ (1970) (emphasis added).

A collective bargaining agreement is an effort to erect a system of industrial selfgovernment. When most parties enter into a contractual relationship they do so voluntarily in the sense that there is no real compulsion to deal with one another, as opposed to dealing with other parties. This is not true of the labor agreement. The choice is generally not between entering or refusing to enter into a relationship, for that in all probability pre-exists the negotiations. Rather it is between having the, relationship governed by an agreed-upon rule of law or leaving each and every matter subject to a temporary resolution dependent solely upon the relative strength, at any given moment, of the contending forces. United Steelworkers v. Warrior \& Gulf Navigation Co., 363 U.S. 574, 580 (1960).

See also Consolidated Edison Co. v. NLRB, 305 U.S. 197, 232, 236 (1938); Jacobs Mfg. Co., 94 N.L.R.B. 1214, 1218, 1231 (1951).

THE FOLLOWING HEREINAFTER CITATION WILL BE USED IN THIS NOTE:

aba labor Relations Section, The Developing Labor Law (1971) [hereinafter cited as Developing Labor Law].

2. See generally Developing Labor Law 302-04, 323-24, 332-38, 340-43, 462-79; Wollett, The Duty to Bargain Over the "Unwritten" Terms and Conditions of Employment, 36 TEXAS L. Rev. 863 (1958); Note, Restrictions on Management Rights-Union Negotiation Waiver, 30 LA. L. REv. 691 (1970); Note, Satisfying the Duty to Bargain During the Term of the Collective Bargaining Agreement Relative to Conditions of Employment Not Covered by the Agreement, 1963 WASH. U.L.Q. 263 (1963). 
8(d) of the National Labor Relations Act ${ }^{3}$ (Act) and collective bargaining agreement clauses dealing with waiver of bargaining rights, management rights, and arbitration. The structure of the analysis of arbitration will be influenced by the National Labor Relations Board's (Board) recent decision in Collyer Insulated Wire ${ }^{4}$ which held that, under certain circumstances, parties would be required to utilize arbitration procedures specified in the collective bargaining agreement-rather than be permitted to resort to an unfair labor practice proceeding before the Board. Because the Board's position will render arbitration clauses increasingly important in mid-term modification situations, this Note will discuss arbitration clauses and the Collyer decision after examining the options provided by the other statutory and contractual components.

\section{Statutory Regulation of Mid-Term Modifications}

The initial guide for determining the legality of mid-term modifcations of terms and conditions of employment ${ }^{5}$ is section $8(d)^{6}$ of the

3. 29 U.S.C. $\S 158$ (d) (1970) [for convenience, this statutory section will be referred to throughout the Note as section 8 (d)]. Failure to comply with the provisions of section $8(d)$ will give rise to a section $8(a)(5)$ or $8($ b) (3) violation for failure to bargain in good faith. Section 8 (a)(5) makes an employer's refusal to bargain an unfair labor practice, and section $8(\mathrm{~b})(3)$ constitutes the counterpart provision relating to labor organizations. $I d$. $\$ 158(\mathrm{a})(5),(\mathrm{b})(3)$.

4. 192 N.L.R.B. No. 150, 77 L.R.R.M. 1931 (1971).

5. At the outset, it should be noted that section 8 (d) refcrs only to mandatory subjects of bargaining. Unilateral action taken with regard to permissive subjects of bargaining may be in breach of contract, but it does not constitute a violation of the Act. Pittsburgh Plate Glass Co. v. Local 1, Allied Chem. \& Alkali Workers, 404 U.S. 157, 185 (1971). For a catalogue of mandatory (for example, profit sharing plans, safety rules, wages) and permissive (for example, union label, internal union affairs) subjects of bargaining, see DEVELOPING LABOR LAW 389. 435.

6. Section $8(d)$ in pertinent part states:

[T] he duty to bargain collectively shall also mean that no party to such contract shall terminate or modify such contract, unless the party desiring such termination or modification-

(1) serves a written notice upon the other party to the contract of the proposed termination or modification sixty days prior to the expiration date thcreof, or in the event such contract contains no expiration date, sixty days prior to the time it is proposed to make such termination or modification;

(2) offers to meet and confer with the other party for the purpose of negotiating a new contract or a contract containing the proposed modifications;

(3) notifies the Federal Mediation and Conciliation Service within thirty days after such notice of the existence of a dispute, and simultaneously therewith notifies any State or Territorial agency established to mediate and conciliate disputes within the State or Territory where the dispute occurred, provided no agreement has been reached by that time; and

(4) continues in full force and effect, without resorting to strike or lockout, all the 
Act, which regulates the conduct of both labor and management when making such modifications. Relevant provisions in section 8(d) allow modifications to be effected but only subsequent to utilization of specified notification and bargaining procedures. ${ }^{7}$ However, when the contemplated modification alters terms and conditions of employment "contained in a contract," no change may be made without the mutual consent of the contracting parties. ${ }^{8}$ Thus, ostensibly the statutory scheme governing mid-term modifications is relatively un-

terms and conditions of the existing contract for a period of sixty days after such notice is given or until the expiration date of such contract, whichever occurs later.

[T] he duties so imposed shall not be construed as requiring either party to discuss or agree to any modification of the terms and conditions contained in a contract for a fixed period, if such modification is to become effective before such terms and conditions can be reopened under the provisions of the contract. Any employee who engages in a strike within the sixty-day period specified in this subsection shall lose his status as an employee of the employer engaged in the particular labor dispute, for the purposes of sections $[8,9$, and 10 of this Act, as amended,] but such loss of status for such employee shall terminate if and when he is reemployed by such employer. 29 U.S.C. $\$ 158(d)$ (1970).

For convenience, when a distinction is necessary, the first portion of the statute and subsections (1)-(4) will be referred to as the "8(d) bargaining procedures," and the latter portion will be referred to as the "8(d) mutual consent provisions."

7. See $\$ 7(d)(1)-(4)$ set forth in note 6 supra.

8. The legislative history on the provisions of section $8(d)$ concerning mid-term modification is rather scanty. The House Conference, which produced the section in its finished form, in its report largely reiterates the wording of the mutual consent provision concerning modifications of terms "contained in a contract." It is noteworthy, especially with regard to the later discussion of Collyer Insulated Wire, see notes 80-98 infra and accompanying text, that the report notes the deletion from the Conference Bill of the Senate amendment which could have been construed to require compulsory arbitration of grievance or contract interpretation disputes. House Conf. ReP. No. 510, 80th Cong., 1st Sess. 25 (1947). This omission indicated an unwillingness to change the bargained-for agreement without mutual consent.

Senator Taft, in a summary of differences between the Senate-passed bill and the Conference Agreement, indicated the relationship between the modification procedures and the provision allowing refusal to modify:

There is clarifying language [in $\S 8(\mathrm{~d})$ ] providing that the 60 day's notice provisions should not be construed as requiring either party to discuss or agree to any modification of terms or conditions contained in a contract during the life of the contract . . . 93 CoNG. Rec. 6444 (1947).

In further clarification of the ambit of the mutual consent provision of section 8(d), Senator Taft stated that the interpretation that "parties will be bound by the contract without further opportunity for bargaining" is incorrect:

It [\$ 8(d)] merely provides that either party to a contract may refuse to change its terms or discuss such a change to take effect during the life thereof without being guilty of an unfair labor practice. Parties may meet and discuss the meaning of their contraet and may agree to modifications on change of circumstances, but it is not mandatory that they do so. Id. at 6860 . 
complicated: ${ }^{9}$ the party desiring change must engage in good faith bargaining pursuant to sections $8(\mathrm{~d})(1)$-(4) bargaining procedures before making any modification, although modification is allowable after impasse; ${ }^{10}$ however, the "mutual consent" provision of section 8(d) permits either party to veto the proposed modification if the change would alter a term or condition of employment "contained in a contract."

\section{Statutory Requirement of Mutual Consent for Bargaining and Modification}

In order to determine when section 8 (d) bars bargaining or modification without the mutual consent of the contracting parties, it is necessary to determine the meaning which the Board and courts attribute to "terms and conditions contained in a contract." Clearly, where the proposed modifications directly contradict the written terms of the agreement," unilateral action after impasse will be held impermissible. ${ }^{12}$ At a less obvious level, moreover, the Board has recently held that a matter associated with-but not actually written

9. The apparent simplicity of the statutory scheme is deceptive because case law has broadened the scope of section 8(d) mutual consent provisions. The cases are legion wherein parties, acting on mid-term modifications without bargaining, evidently misconstrued the scope of $\S 8$ (d) modification provisions and the difficulty of avoiding them with vaguely worded contractual clauses. See, e.g., American Smelting \& Ref. Co., 167 N.L.R.B. 204 (1967), enforccd, 406 F.2d 552 (9th Cir.), cert. denied, 395 U.S. 935 (1969); Long Lake Lumber Co., 160 N.L.R.B. 1475 (1966); Huttig Sash \& Door Co., 154 N.L.R.B. 1567 (1965) (an unfair labor practice was determined, but the Board dismissed as de minimis), vacated and remanded, 380 F.2d 628 (D.C. Cir. 1967); LeRoy Mach. Co., Inc., 147 N.L.R.B. 1431 (1964); Cloverleaf Div. of Adams Dairy Co., 147 N.L.R.B. 1410 (1964).

10. Cessna Aircraft, 172 N.L.R.B. No. 86,68 L.R.R.M. 1471, 1472 (1968). The ability to make a modification after impasse is rarely affirmed by the Board. Howevcr, there are many cases in which the employer attempted unilateral action with respect to a matter not within the mutual consent provisions of section $8(\mathrm{~d})$ before bargaining, and the Board order required him to return matters to the status quo until he accomplishes good faith bargaining and the union either refuses to bargain or there is an impasse. See, e.g.. Gravenslund Operating Co., 168 N.L.R.B. 513, 514 (1967); American Smelting \& Ref. Co., 167 N.L.R.B. 204, 212 (1967); Cloverleaf Div. of Adams Dairy Co., 147 N.L.R.B. 1410, 1415 (1964). Compare NLRB v. Burns Int'l Security Serv., Inc., 40 U.S.L.W. 4499 (U.S. May 15, 1972), where the Supreme Court held that, while successor employers may be bound to recognize incumbent unions, they are not bound to observe the substantive terms of a collective bargaining agreement negotiated by their predecessors but not voluntarily assumed by them.

I1. See Standard Oil Co. (Ohio), 174 N.L.R.B. No. 33, 70 L.R.R.M. 1115 (1968).

12. Id., 70 L.R.R.M. at 1116; Firestone Synthetic Rubber \& Latex Co., 173 N.L.R.B. $1174,1175-76$ (1968) (the trial examiner stated that the employer could under ordinary circumstances refuse to bargain over matters raised by the union since the items were contained in the contract, but that since the contract had expired, bargaining was required; while the Board 
into-the contract was within the mutual consent provision of section 8(d).${ }^{13}$ Consequently, any change which directly affects a term of the contract, either by contradieting it or by adding new terms which alter its effect, will apparently be within the provision of section 8(d) requiring mutual consent for the mid-term modification. ${ }^{14}$

While neither the Board nor the courts have displayed an inclination to further expand the meaning of "terms and conditions contained in a contract," 15 the mutual consent provision has been an effective weapon for combating unilateral changes. For example, it has been held that, where a collective bargaining agreement fails to incorporate a particular clause, any benefits accruing to either party from omission of the clause are "frozen" as a term or condition of employment for the contract's duration, absent alteration by mutual consent of the contracting parties; ${ }^{16}$ consequently, unilateral modifications altering "frozen" benefits are violative of section 8(d), regardless of the merit of the changes. ${ }^{17}$

It should be noted that, although a refusal to bargain on the part of the non-modifying party is justified where the proposed change

otherwise agreed with the trial examincr, it found the contract had not expired). See Proctor Mfg. Corp., 131 N.L.R.B. 1166, 1170 (1961) (one party cannot compel the other to renegotiate existing terms of a contract).

13. C \& S Indus., 158 N.L.R.B. 454 (1966). In that case the Board determined that, even had the employer bargained in good faith to the point of impasse before instituting an incentive program, a modification of the terms "contained in a contract" would result inasmuch as incentivcs were "unseparably bound up" with the wages which had been specified in the contract. Id. at 459.

14. Whatever distinction there may be betwcen the bargaining duty in matters not contained in a contract and matter denominated "unwritten terms of a contract," see Long Lake Lumber Co., 160 N.L.R.B. 1475, 1479 (1966), an unwritten term of a contract is not so "contained in a contract" as to be within the section 8(d) mutual consent provision. In Long Lake, while finding that the long-standing Monday-Friday work week for maintenance men was an unwritten term of the contract, the Board merely noted the employer's duty to bargain over any change, indicating that the matter was not "frozen in" by the mutual consent provision. See also American Smelting \& Ref. Co., 167 N.L.R.B. 204 (1967).

15. It has been indicated that recently "the Board seems to have given increased attention to contract interpretation under section 8 (d) and to limiting the freedom to engage in unilateral changes of operation, even after bargaining." DEvELOPING LABOR LAW 476. However, a careful reading of the cases cited to support this statement indicates that, while the Board may be making more use of the mutual consent provision of seetion 8(d), it is not expanding the scope of its coverage.

16. NLRB v. Scam Inst. Corp., 394 F.2d 884 (7th Cir.), cert. denied, 393 U.S. 980 (1968). In that case, the court held that section 8 (d) precluded the employer from placing a "nonduplicating" clause in the employees' health insurance policy after impasse. A "nonduplicating" clause prevents the policy in which it is placed from being utilized to duplicate payments made to the beneficiary pursuant to insurance coverage.

17. 394 F.2d at 887 . 
affects a term or condition contained in the collective bargaining agreement, an assumption evidently exists that bargaining over a matter contained in a contract is never foreclosed until the party who can refuse to bargain over or allow a modification actually exercises that prerogative. ${ }^{18}$ In any event, unilateral action by the modifying party constitutes a violation of the duty to bargain in contravention of either section $8(a)(5)$ or $8(b)(3)$, and the remedy for such a violation is a bargaining order.

Thus, absent contractual provisions which may modify these statutory duties, mutual consent to mid-term modifications will be required when the modification affects an explicit, written term contained in the contract or pertains to a matter "inseparably bound up" with such a term. However, contractual tools may be utilized to alter otherwise binding statutory requirements and thereby permit implementation of mid-term changes without obtaining the other party's consent.

\section{Contractual Modifications of Statutory Duties}

Two frequently used contractual tools, utilized to modify the statutory requirements imposed by section 8(d), are waiver and management rights clauses. A third contractual device-the arbitration clause-has achieved a degree of importance warranting a more extended treatment. Accordingly, arbitration clauses will be examined separately after the discussion of waiver and management rights clauses.

\section{Waiver Clauses}

Unless a proposed modification affects existing contractual provisions, thereby triggering the operation of section 8(d) mutual consent provisions, a party may raise for bargaining any matter concerning terms and conditions of employment and, to the extent the party has

18. Cf. Wisconsin So. Gas Co., 173 N.L.R.B. 480, 484-85 (1968); Unit Drop Forge, Div., Eaton Yale \& Towne, 171 N.L.R.B. No. 73, 68 L.R.R.M. 1129, 1132 (1968), modified, 412 F.2d 108 (7th Cir. 1969); Century Papers, Inc., 155 N.L.R.B. 358, 362-63 (1965); Huttig Sash \& Door Co., 154 N.L.R.B. $811,817-18$ (1965), enforced, 377 F.2d 964 (8th Cir. 1967). This tendency of the Board was most evident in Scam Inst. Corp., 163 N.L.R.B. 284 (1967), enforced, 394 F.2d 884 (7th Cir.), cert. denied, 393 U.S. 980 (1968), wherein the Board, while stating that the employer was not at liberty to change or withdraw coverage because the contractual terms covered the matter, was more concerned with the employer's failure to follow the bargaining procedures of section 8(d). Id. at 288. The Court of Appeals for the Seventh Circuit, on the other hand, noted only that the matter was "frozen" as a condition of employment without mutual consent. 394 F.2d at 887. 
control over the matter, ${ }^{19}$ may effect changes after a bargaining impasse has been reached. ${ }^{20}$ In light of this ability, each party may desire the other to waive his right to raise the issue of-or object to-the initiation of mid-term modifications. A primary contractual tool for implementing this goal is a waiver or "zipper" clause incorporated into the collective bargaining agreement.

In an important interpretive decision concerning section 8(d), the Board expressly sanctioned in principle the use of waiver clauses for the limited purpose of foreclosing mid-term bargaining over matters not covered in the collective bargaining agreement. ${ }^{21}$ The Board noted:

[I] the parties originally desire to avoid later discussion with respect to matters not specifically covered in the terms of an executed contract, they need only so specify in the terms of the contract itself. ${ }^{22}$

While waiver clauses were already incorporated in collective bargaining agreements at the time of the decision, the Board's clear approval of their use, albeit only in principle, caused widespread inclusion of such clauses as "boilerplate" in bargaining agreements. ${ }^{23}$

In its broadest form, ${ }^{24}$ a "zipper" clause expresses each party's

\section{See note 41 infra and accompanying text.}

20. See cases cited at note 10 supra.

21. Jacobs Mfg. Co., 94 N.L.R.B. 1214, 1220 (1951). In Jacobs, the Board required an employer to comply with the union's mid-term request to bargain on a pension plan not previously discussed in contract negotiations. Since the subject of pensions was not contained in the contract, it did not fall within the mutual consent provisions of section 8(d), and the employer could not lawfully refuse to bargain.

22. Id.

23. 36 BNA Coll. Barg. Neg. \& Cont. 421-22 (1969).

24. See the first example of a waiver clause set forth below. Waiver clauses normally deal with three types of subjects: matters contained in the contract; matters not in the contract but discussed at negotiations; and matters not contemplated by cither party at the time of negotiation. Three examples which show different means of dealing with these variables follow:

The company and the union, for the life of this agreement, each voluntarily and unqualifiedly waives the rights, and each agrees that the other shall not be obligated, to bargain collectively with respect to any subject or matter referred to, or covered in this agreement, or with respect to any subject or matter not specifically referred to or covered in this agreement even, though such subject or matter may not have been within the contemplation of either or both of the parties at the time they negotiated and signed this agreement. Unit Drop Forge, Div., Eaton Yale \& Towne, 171 N.L.R.B. No. 73, 68 L.R.R.M. 1129 (1969).

In the Unit Drop Forge litigation over this waiver clause, the employer claimed the right to make unilateral changes as to operations modifications over which a management rights clause gave him exclusive control. However, the change also affected incentive pay, a matter on which agreement was required before modification. The Board held that a broad zipper clause does not waive the union's right to bargain, but that the topic over which unilateral control is sought 
agreement to waive his right-and the duty of the other party ${ }^{25}$ - to bargain with regard to matters included in or omitted from the

must be specifically delineated. $I d$. at 1131 . For a similar result with the same waiver clause see Rockwell-Standard Corp., Trans. \& Axle Div., Forge Div., 166 N.L.R.B. 124 (1967), enforced. 410 F.2d 953 (6th Cir. 1969).

[F]or the life of this Agreement each voluntarily and unqualifiedly waives the right, and each agrees that the other shall not be obligated, to bargain collectively with respect to any subject or matter referred to or covered by this agreement, or with respect to any subjects or matters not specifically referred to or covered by this Agreement which were discussed during the negotiation of this Agreement. Westinghouse Elec. Corp., Bettis Atomic Power Lab., 153 N.L.R.B. 443, 445 (1965).

In the Westinghouse litigation, the Board found no unlawful refusal to bargain in the employer's unilateral subcontracting because of the lack of harm to the unit employees by the action. Id. at 447-48. Bargaining history showed that the parties had discussed the matter of subcontracting and that the employer had informally agreed to discuss subcontracting on a "case by case" basis. The trial examiner's opinion, which is not contradicted by the Board on this point, indicates that if there had not been the renewed interest shown in the informal agreement, the waiver clause would have waived the union's right to bargain on this matter since it was specifically within the matters waived by the clause. Id. at 456 .

The parties acknowledge that during negotiations which resulted in this Agreement, each had the unlimited right and opportunity to make demands and proposals with respect to any subject or matter of collective bargaining, and that the understanding and agreements arrived at by the parties after the exercise of that right and opportunity are set forth in this Agreement. Therefore, the Employer and the Union, for the life of this Agreement, each voluntarily and unqualifiedly waives the right and each agree that the other shall not be obligated to bargain collectively with respect to any subject matter not specifically referred to or covered in this Agreement, even though such subjeets or matters may not have been within the knowledge or contemplation of either or both of the parties at the time they negotiated or signed this Agreement. C \& C Plywood, 148 N.L.R.B. 414, 422 (1964), enforcement denied, 351 F.2d 224 (9th Cir. 1965), rev'd, 385 U.S. 421 (1967).

In $C \& C$ Plywood, the employer, under authority of a clause reserving to the employer the right to make "premium pay," unilaterally instituted "premium pay" for certain employees based on production levels. The union contended that the pay change was incentive rather than premium pay and that the employer had a duty to bargain. Over the employer's contention that the dispute was merely a matter for contract interpretation and arbitration, the Board held, without discussing the effect of the waiver clause, that the employer had a duty to bargain. Id. at 417.

Review of these and other cases dealing with waiver clauses indicates that the literal meaning of their content is given limited weight by the Board.

25 . In waiving both the right and obligation to bargain, the parties seemingly shed themselves of their statutory rights and return to a "state of nature" wherein the employer may act unilaterally. The Board and courts, while allowing contractual waiver of statutory rights, Ador Corp., 150 N.L.R.B. 1658 (1965), have been extremely reluctant to do so. See notes $26-31$ infra and accompanying text. For the reverse type of approach, where the parties seemingly create bargaining duties beyond those required by the statute, see Federal Compress \& Warehouse Co., 166 N.L.R.B. 664 (1967), where the contract provided:

This agreement constitutes the sole and entire agreement between the parties . . . . During the terms of this agreement no change or modification shall be binding upon either of the parties hereto unless this same shall be reduced to writing and signed by both parties hereto. Id. at 671 . 
collective bargaining agreement, regardless of whether unspecified matters were previously contemplated by the parties. Since a "zipper" clause ostensibly waives the union's right to enforce the employer's duty to bargain, this contractual device would appear to authorize unilateral action by the employer without consultation with the union. However, generally-worded "zipper" clauses do not operate to terminate the union's right to bargain in response to a proposed mid-term modification ${ }^{26}$ since, to constitute a waiver of the right to require the employer's use of section $8(\mathrm{~d})$ bargaining procedures, "clear and unmistakable" contractual language relinquishing bargaining rights as to the specific matter raised must be present. ${ }^{27}$

Despite the inability of "boilerplate" waiver clauses to give the employer unfettered control over a matter and the necessity of using specific management rights clauses to achieve that purpose ${ }^{28}$ waiver clauses are presumably effective to preclude a party from raising new issues or demands during the term of the contract. ${ }^{29}$ In addition, the union's right to raise a matter not covered by the collective agreement during the contract's term may be deemed to be waived by bargaining history which demonstrates that the union made, but later dropped, demands during the contract negotiations. ${ }^{30}$ It should be noted, however, that such conduct is not a waiver of the right to bargain on a matter raised by the other party, unless it is clearly demonstrated that the union's interest in the matter was "consciously and clearly" waived during the contract negotiations. ${ }^{31}$

26. A myriad of cases exists wherein the employer has taken action unilaterally under the mistaken notion that the literal meaning of the waiver and management rights clauses served to waive the union's right to bargain. See, e.g., Rockwell-Standard Corp., 166 N.L.R.B. 124 (1967): Crescent Bed Co., 157 N.L.R.B. 296 (1966); C \& C Plywood Corp., 148 N.L.R.B. 414 (1964); LeRoy Mach. Co., Inc., 147 N.L.R.B. 1431 (1964); Tide Water Assoc. Oil Co., 85 N.L.R.B. 1096 (1949).

27. Three cases illustrate instances wherein an express waiver has been found. Huttig Sash \& Door Co., Inc., 154 N.L.R.B. 1567, 1576 (1965) (waiver by express provision of the management rights clause); General Motors Corp., Buick-OIdsmobile-Pontiac Assembly Div., 149 N.L.R.B. 396, 400 (1964); LeRoy Mach. Co., Inc., 147 N.L.R.B. 1431, 1432 (1964) (waiver by management rights clause held sufficient as to one action by management but insufficient to permit other disputed action). .

In other cases, the waiver has been determined to be too vague. See, e.g., Timken Roller Bearing Co. v. NLRB, 325 F.2d 746, 751 (6th Cir.), cert. denied, 376 U.S. 971 (1964); Smith Cabinet Mfg. Co., 147 N.L.R.B. 1506, 1508 n.2 (1964); Cloverleaf Div. of Adams Dairy Co., 147 N.L.R.B. 1410,1412 (1964).

28. See notes $36-41$ infra and accompanying text.

29. Jacobs Mfg. Co., 94 N.L.R.B. 12 [4, 1220 (1951). See also New York Mirror, 151 N.L.R.B. 834,840 (1965).

30. Jacobs Mfg. Co., 94 N.L.R.B. 1214, 1228 (1951).

31. See note 37 infra and accompanying text. 
If a broad "zipper" clause or the parties' bargaining history serves to waive the union's right to raise new matters during the term of the collective agreement, it would seem logical that the commonly-used mutual waiver clause would similarly terminate management's right to raise a matter for mid-term bargaining and modification. In authorizing waiver clauses to preclude mid-term bargaining, in one case the Board found no distinction between management and labor ${ }^{32}$ If no distinction can be discerned, both parties would, in effect, be precluded from effecting any changes without mutual consent inasmuch as a "zipper" clause clearly does not operate to allow unilateral action by management. However, perhaps because there is some recognition of an inherent management right to initiate what it deems to be necessary changes, ${ }^{33}$ the mutual waiver "zipper" clause has not been construed to prevent management from requesting bargaining concerning a mid-term modification. For instance, in Unit Drop Forge $^{34}$ the Board's order that the employer utilize section 8(d) bargaining procedures and bargain to agreement or impasse before instituting unilateral changes indicates that the broad mutual waiver clause contained in the collective agreement did not preclude the employer, as it would the union, from demanding mid-term changes with respect to matters not contained in the contract.

In brief, "zipper" clauses serve a critical, albeit limited, role in relieving a party's statutory obligations. Although a generallyworded waiver clause will not be deemed to permit unilateral modification without prior bargaining, this contractual tool does operate to preclude raising new matters for bargaining during the existence of the collective agreement, thereby promoting the purpose of achieving contractual stability between the parties. Effecting the purpose of providing the employer ample flexibility to take unilateral action without consulting the employee's representative requires utilization of other contractual techniques or demonstration of a functional equivalent of such authorization by the representative's conduct during contractual negotiations.

32. Jacobs Mfg. Co., 94 N.L.R.B. 1214, 1228 (1951).

33. While the "residual rights" theory, which claims that the management retains all powers not specifically given away in the contract, has been discredited in the interpretation of the national labor policy, see Cox \& Dunlop, The Duty to Bargain Collectively During the Term of an Existing Agreement, 63 HARv. L. REv. 1097, 1116-20 (1950), it still retains some vitality among arbitrators. See, e.g., Owens-1llinois Inc., 70-2 CCH LAB. ARB. Awards 18606 (1970) (Stouffer, Arbitrator); C.G. Bretting Mfg. Co., 70-1 CCH LAB. ARB. Awards 98167 (1969) (Solomon, Arbitrator); Cook \& Brown Lime Co., 50 Lab. Arb. 597 (1968) (Rice, Arbitrator).

34. 171 N.L.R.B. No. 73, 68 L.R.R.M. 1129 (1968). 


\section{Management Rights Clauses}

It appears from those cases in which a full waiver of bargaining rights as to a particular subject has been found that the management rights clause ${ }^{35}$-by which the employer expressly claims unilateral control over specific items-is a more effective contractual tool for eliminating the employer's duty to consult with the union. For instance, in LeRoy Machine Co., Inc. ${ }^{36}$ the collective bargaining agreement contained a broad management rights clause ${ }^{37}$ which included the specific right to determine qualifications for employment. Although management's refusal to bargain over wage rates for new

35. The following clause was held to waive bargaining rights as to a dispute over the right to shut down a line of products:

The management of the Company's plant and the direction of its working forces, including the right to establish new jobs, abolish or change existing jobs, increase or decrease the number of jobs, change materials, processes, products, equipment and operations shall be vested exclusively in the Company .... Subject to the provisions of this agreement, the Company shall have the right to . . . lay off employees because of lack of work or other legitimate reasons .... Ador Corp., 150 N.L.R.B. 1658, 1659-60 (1965).

Some commentators have assumed that "boilerplate" management rights clauses will not serve to waive bargaining rights over specific matters. See Developing LABOR LAw 334. However, on a closer reading of the cases cited for this point in Developing LABOR LAw one is not convinced of this purported trend. In Proctor Mfg. Corp., 131 N.L.R.B. 1166, 1168 (1961), the ineffective management rights clause was so broad that no standard of specificity may be developed from the decision. In Tide Water Assoc. Oil Co., 85 N.L.R.B. 1096 (1949), the management rights clause dealt specifically with waiver of bargaining rights with respect to retirement plans then in existence. That the employer was required to bargain mid-term on a newly proposed plan is not surprising since failure to include specific matters when otherwise being specific indicates an intent to exclude. Further, in Huttig Sash \& Door Co., 154 N.L.R.B. 1567 (1965), the Board approved a trial examiner's decision holding that a lengthy management rights clause which did not specifically include the right to determine unilaterally wage rates of new jobs nonetheless covercd the change, since the union could have specifically excluded that management right had it so desired. $I d$. at 1576 .

For a problem-oriented consideration of management rights clauses, see Note, Restriction on Management Rights-Union Negotiation Waiver, supra note 2.

36. 147 N.L.R.B. 1431 (1964).

37. The Company retains the sole right to manage its business and direct the working force, including the rights to decide the number and location of plants . . . to determine whether and to what extent the work required in its business shall he performed by employees covered by this agreement; . . . including the sole right to discipline, sujpend and discharge employees for cause; to hire, lay off, assign, transfer, promote and determine the qualifications of employees; . . . subject only to such regulations governing these rights as are expressly provided in the Agreement.

The above rights of management are not all inclusive, but indicate the type of matters or rights which belong to and are inherent to management. Any of the rights, powers, and authority the Company had prior to entering this collective bargaining are retained by the Company, except as expressly and specifically abridged, delegated, granted, or modified by this Agreement. Id. at 1436 n.5 (emphasis added). 
jobs was determined to be an unfair labor practice due to the absence of a waiver of bargaining rights, ${ }^{38}$ the employer's unilateral institution of, and refusal to bargain over, a physical examination requirement for current employees was viewed as proper since the management rights clause expressly gave the employer unilateral control over the matter. ${ }^{39}$

In addition to the operation of a management rights clause, the right to bargain over specific matters may be deemed to be waived by reference to bargaining history. The standard utilized in determining whether, by its conduct during collective bargaining, the union waived its right to bargain is, however, quite stringent. It must be demonstrated that, after conscious exploration of the subject matter during negotiations, the union "consciously yielded [its] . . . interest to be notified."40

In summary, absent contractual clauses establishing grievance and arbitration procedures, mid-term modifications are subject to relatively well-defined guidelines. First, if the modification either affects or is "inseparably bound up" with a term or condition of employment contained in the contract, mutual consent of the parties is required before bargaining or modification may proceed. If mutual consent is not required, either party may make a modification (the union only to the extent not pre-empted by the employer's inherent right to manage the enterprise $\mathrm{e}^{41}$ ) after bargaining and notification procedures provided by section $8(d)(1)$-(4) have been properly utilized and an impasse has been reached. The employer enjoys the right to unilaterally modify terms and conditions of employment only if bargaining rights with respect to the particular matter raised have been clearly and unmistakably waived by the union in the collective agreement by means of a management rights clause or by bargaining history. Finally, the union may be precluded from demanding a midterm modification if it has waived its right to "demand" bargaining through a "zipper" clause or by raising and abandoning the issue at the bargaining table.

38. Id. at 1431 .

39. Id. at 1432. The trial examiner's decision was overruled on the same matter. Id. at 1438.

40. New York Mirror, 151 N.L.R.B. 834, 840-41 (1965). See also Press Co., 121 N.L.R.B. 976, 978 (1958).

41. See, e.g., N.L.R.B. v. Blades Mfg. Corp., 344 F.2d 998, 1004-05 (8th Cir. 1965); N.L.R.B. v. Montgomery Ward \& Co., 157 F.2d 486, 496 (8th Cir. 1946); Raleigh Water Heater Mfg. Co., 136 N.L.R.B. 76, 80 (1962); Elk Lumber Co., 91 N.L.R.B. 333, 337-38 (1950). See also UAW v. Wisconsin Emp. Rel. Bd., 336 U.S. 245 (1949). 


\section{Contractual Modifications of Statutory Duties: ARBitration Clauses}

In considering the parameters of permissible action in mid-term modifications, it has been assumed thus far that it is a realistic possibility for the employer or the union to initiate mid-term action after impasse. However, neither party will ordinarily desire to risk disrupting industrial relations by instituting a modification totally unacceptable to the other party while a collective bargaining agreement is in existence. ${ }^{42}$ Nonetheless, absent a system of industrial dispute resolution, the possibility exists of bargaining to impasse followed by a unilateral modification of the collective agreement.

Perhaps the greatest deterrent to reaching an impasse over midterm modifications is the inclusion in the collective agreement of clauses which the arbitrator may be called upon to decide. ${ }^{33}$ Questions which the parties may wish to have resolved include whether the subject matter of the modification is "arbitrable;" 44 the manner in which, at the time the collective agreement was executed, the parties intended that their rights and duties be arranged with respect to the matter sought to be modified; and whether the arbitrator enjoys power to institute necessary changes.

The breadth of the arbitration clause will also determine the threshold issue of arbitrability, but "the desirability of arbitration over alternative methods of settling unresolved grievances require[s] the courts to decide the more usual kinds of substantive arbitrability in favor of arbitration . . ." 45 When enforcement of an arbitration clause is sought in court, it may not be denied unless "it may be said with positive assurance that the arbitration clause is not susceptible

42. Cox, Refleetions Upon Labor Arbitration, 72 HARv. L. REv. 1482, 1490-9I (1959). See United Steelworkers v. Warrior \& Gulf Navigation Co., 363 U.S. 574, 578 (1960); Collyer Insulated Wire, 192 N.L.R.B. No. 150, 77 L.R.R.M. 1931, 1937 (1971).

43. See generally Cushman, Arbitration and the Duty to Bargain, 1967 WIs. L. Rev. 612 (1967); Wollett, The Duty to Bargain Over the Unwritten Terms and Conditions of Employment, supra note 2; Note, Satisfying the Duty to Bargain During the Term of a Contract, supra note 2. See also Developing Labor Law ch. 18; Cox, supra note 42.

44. For a pre-1960 (see note 45 infra) discussion which is still helpful on the difference between the court's decision on "arbitrability" and the arbitrator's decision on "jurisdiction," see Cox, supra note 42, at 1507-18.

45. Smith \& Jones, The Impact of the Emerging Federal Law of Grievance Arbitration on Judges, Arbitrators, and Parties, 52 VA. L. Rev. 831, 832 (1966). At the outset it must be noted that there is a strong presumption in favor of arbitrability, fostered initially by the 1960 "Steelworker's Trilogy" (United Steelworkers v. Warrior \& Gulf Navigation Co., 363 U.S. 574 (1960); United Steelworkers v. American Mfg. Co., 363 U.S. 564 (1960); and United 
of an interpretation that covers the asserted dispute." 40 The broadest clauses allow arbitration of contract interpretation differences and of any local dispute between the parties. ${ }^{47}$ A more commonly used clause limits arbitration to disputes concerning the terms of the agreement. ${ }^{48}$ Other clauses designate specific issues as arbitrable ${ }^{49}$ or

Steelworkers v. Enterprise Wheel \& Car Corp., 363 U.S. 593 (1960)), nurtured by voluminous literature thereafter, modified and elucidated by the 1962 cases (Sinclair Ref. Co. v. Atkinson [Sinclair 1], 370 U.S. 195 (1962); Atkinson v. Sinclair Ref. Co. [Sinclair II], 370 U.S. 238 (1962); and Drake Bakeries, Inc. v. Local 50, Bakery Workers, 370 U.S. 254 (1962)), and expanded by the 1964 cases (Carey v. Westinghouse Elec. Corp., 375 U.S. 261 (1964), and John Wiley \& Sons v. Livingston, 376 U.S. 543 (1964)). A major step was taken in 1970 when the Supreme Court overruled Sinclair I and held that the Norris-LaGuardia Act's absolute prohibition of labor injunctions must be reconciled with the developing use and value of the arbitral process and that where an issue was arbitrable under a contract, a contractual no-strike clause could be enforced injunctively. Boys Markets, Inc. v. Clerks Union, 398 U.S. 235, 250 (1970).

46. United Steelworkers v. Warrior \& Gulf Co., 363 U.S. 574, 582-83 (1960). For an extensive survey of the Trilogy's effect on courts' decisions enforcing arbitration, see Smith \& Jones, supra note 45 , at $838-66$.

47. The arbitration clause in the contract between the United Steelworkers and Warrior \& Gulf Navigation Co. was interpreted to allow the matter to be arbitrated at least to determine whether the disputed matter was solvable by arbitration. In the subsequent arbitration, it was decided that the matter was arbitrable. Warrior \& Gulf, 36 Lab. Arb. 695 (1961) (Holly, Arbitrator). The clause provided:

Issues which confict with any Federal statute in its application as established by Court procedure or matters which are strictly a function of management shall not be subject to arbitration under this section.

Should differences arise between the Company and the Union or its members employed by the Company as to the meaning and application of the provisions of this Agreement, or should any local trouble of any kind arise, there shall be no suspension of work on account of such differences but an earnest effort shall be made to settle such differences immediately in the following manner:

....

Fifth, if agreement has not been reached the matter shall be referred to an impartial umpire for decision. 363 U.S. 574, 576 (1960).

A clause with perhaps even broader scope is illustrated by the following:

[A]ny dispute involving the interpretation, application or alleged violation of any provision of this Agreement, or any alleged action of the Company or its supervisors which the employee fecls unjustly or unlawfully affects his job or any benefits arising out of his job [will be arbitrated]. Pacific Power \& Light Co., and Pacific Power Council of the Int'l Bhd. of Elec. Workers, 1 CCH LaB. L. Rep., Union Contracts ARBITRation If 59,928 at $6.0-7.0$.

48. Any disputes, misunderstandings, differences or grievances arising between the parties as to the meaning, interpretation and application of the provisions of this agreement . . . may be submitted to the Board of Arbitration for decision . . . .

The arbitrator may interpret this agreement and apply it to the particular case under consideration but shall, however, have no authority to add to, subtract from, or modify the terms of the agrecment. United Steelworkers v. American Mfg. Co., 363 U.S. 564, 565 n.1 (1960).

49. Any controversy which has not been satisfactorily adjusted under the Grievance Procedure and which involves. A. The discharge of an Employee or B. The interpretation of provisions of this contraet or $\mathrm{C}$. An alleged violation of the contract may be submitted 
exclude from general arbitrability a particular subject, such as shift transfers ${ }^{50}$ or new job rates. ${ }^{51}$ Under the broad standards of arbitrability enunciated in 1960 by the Supreme Court in the Steelworkers Trilogy, ${ }^{52}$ there would be judicially enforceable (threshold) arbitrability ${ }^{53}$ of most issues if either the broad clause or the more common, limited clause were used..$^{54}$ Even if the matter sought to be changed is not clearly controlled by the contract, the question of whether the contract allowed a party unilateral control over the matter in dispute would arguably be arbitrable. ${ }^{55}$

The presumption of arbitrability arising from judicial predilections toward encouraging industrial self-government is, however, not irrebuttable. In instances where clauses expressly exclude matters from arbitration, courts will frequently deny threshold arbitrability. ${ }^{56}$ Moreover, even if threshold arbitrability is found by the

to the Arbitration Committee. . . . Union Carbide Corp., Nuclear Div. and Atomic Trades and Labor Council; contract expiring June, 1972, reported in BNA, Collective Bargaining-Negotiations and Contracts 51:263 (1972).

50. Shift assignments are made by the Company in accordance with production requirements. Both thc Company and the Union recognize that some employees : . . may desire transfer to another shift .... . The shift change shall be made as openings occur and production requirements permit and, where possible, in the order that the requests are reccived by the department. Grievances filed under this Section of the Agreement shall be subject to the Grievance Procedure up to but not including Step Four, Arbitration. General Dynamics Corp., Convair Div. and Machinists; contract expiring March, 1972, reported in BNA, Collective Bargaining-Negotiations and Contracts $51: 265$ (1972).

51. When the Company adds a new job to the bargaining unit it will determine the base rate and notify the Union. If the Union disagrees with the base rate determined by the Company, it may institute a grievance . . . in the Third Step of the Grievance Procedure ... . If no agreement is reached, the grievance may be referred to the regular Fourth Step of the Grievance Procedure but may not be arbitrated. Campbell Soup Co. and Meat Cutters; contract expiring March, 1972, reported in BNA, Collective BARGAiNING-NEGOTIATIONS AND CONTRACTS 51:264 (1972).

52. See note 45 supra.

53. See note 44 supra.

54. See note 45 supra.

55. See, e.g., Humble Oil \& Rèf. Co. v. Teamsters Local 866, 447 F.2d 229 (2d Cir. 1971); Local 198, Rubber Workers v. Interco Inc., 415 F.2d 1208, 1211 (8th Cir. 1969); Local 24, IBEW v. Hearst Corp., 352 F.2d 957 (4th Cir. 1965), cert. denied, 383 U.S. 937 (1966); Local 1987, IBEW v. Control Prod. Co., 330 F. Supp. 250 (W.D. Pa. 1971); Dean Truck Line, Inc. v. Teamsters Local 667, 327 F. Supp. 1335, 1340 (N.D. Miss. 1971); Smith \& Jones, supra note 45 , at $858-60$.

56. NLRB v. Community Motor Bus Co., 439 F.2d 965 (4th Cir. 1971) (employer had expressly reserved the right to rcfuse to hire employees guilty of illegal picketing activity, thus there was no duty to arbitrate grievances on the mattcr); Halstcad \& Mitchell Co. v. Unitcd Stcelworkers, 421 F.2d 1191 (3d Cir. 1969) (if the mariagement rights clause is specific in giving the employer unilateral control to determine layoffs, and the arbitration clause excludes 
court, the arbitrator himself may decide that the contract does not authorize his arbitral jurisdiction over the disputed matter. ${ }^{57}$ When either the courts or arbitrators find a matter unarbitrable, the parties are left to determine their rights within the previously outlined statutory and case-law guidelines for mid-term modification conduct. ${ }^{58}$

If the breadth of the arbitration clause renders the subject matter of the mid-term modification arbitrable, the authorized scope of the arbitrator's award must be determined. The proper scope of the award will be controlled largely by the wording of the arbitration clause,,$^{59}$ the bargaining history between the parties, ${ }^{60}$ and the enforceable scope of the management rights clause. ${ }^{61}$ Most frequently, the arbitrator will restrict his award to deciding the manner in which labor and management intended to deal between themselves with respect to the subject matter of the modification-through mutual

from its scope matter covered by the management rights clause, there is no duty to arbitrate); General Tel. Co. v. C.W.A., 402 F.2d 255 (9th Cir. 1968) (grievant, a supervisor, was not an employee within the unit whose grievances employer had decided to arbitrate); Southwestern Bell Tel. Co. v. C.W.A., 324 F. Supp. 830 (S.D. Tex. 197I) (union was not bound to arbitrate its complaint over a mid-term modification because the clause expressly excluded the matter from its scope).

57. See Western Elec. Co., 46 Lab. Arb. 1018, 1021 (1966) (Dugan, Arbitrator) (the standard for courts to follow in enforcing arbitration clauses does not apply to the arbitrator); Master Builder's Ass'n of W. Pa., Inc., 45 Lab. Arb. 892, 893-94 (1965) (McDermott, Arbitrator); Warrior \& Gulf, 36 Lab. Arb. 695, 696 (1961) (Holly, Arbitrator) ("tbe Suprcme Court . . . left the basic question of arbitrability for the Arbitrator to decide"); Smith \& Jones, supra note 45 , at 873 . For an analysis of contractual bases upon which arbitrators may rely in refusing jurisdiction, see $i d$. at 866-85. See also Cox, supra note 42, at 1507-18.

58. Southwestern Bell Tel. Co. v. C.W.A., 324 F. Supp. 830 (S.D. Tex. 1971), illustrates the dangers inherent in such a situation. In Southwestern, the employer unilaterally instituted a mid-term modification of scheduling and seniority which was not within the terms of the contract. The union went on strike in protest, in spite of a no-strike clause. The employer attempted to obtain a Boys Markets ${ }^{\circ}$ injunction to enjoin a breach of the no-strike clause, but its motion was denied since the matter was not arbitrable within the parties' contract. Tluus, there was no trade-off of arbitration for the no-strike pledge.

59. For instance, in Hughes Tool Co., 36 Lab. Arb. 1125 (1960) (Aarron, Arbitrator), the arbitration clause provided: "the arbiters shall not add to, subtract from, change or modify any provision of this agreement," and the arbitrator deemed this controlling on his ability to provide a solution to the dispute.

60. See Plumbing-Heating \& Piping Council, 54 Lab. Arb. 478, 483 (1970) (Eaton, Arbitrator); Bell Tel. Labs., 39 Lab. Arb. 1191, 1205 (1962) (Roberts, Arbitrator) (bargaining history is a proper means of determining what was meant to be subject to arbitration when the parties contend that the contract can be interpreted in opposite ways).

61. See notes 35-39 supra and accompanying text. For instance, in R. H. Macy \& Co., 69$1 \mathrm{CCH}$ LAB. ARB. AWARDS I 8126 (1968) (Epstein, Arbitrator), management's prerogatives were held to allow unilateral action. 
consent, ${ }^{62}$ bargaining,,$^{63}$ or unilateral control. ${ }^{64}$ On the other hand, the parties may allow the arbitrator to engage in "interest arbitration" and decide the substance of the matter himself. ${ }^{65}$ "Interest arbitration" is not frequently authorized by collective bargaining agreements. Accordingly, the standard clause providing that "the arbitrator shall not have power to add to nor subtract from the terms of the Agreement" ${ }^{66}$ would negatively decide the question of whether the

62. See International Shoe Co., 46 Lab. Arb. 752 (1966) (Hilpert, Arbitrator); KeystoneSteel and Wire Co., 45 Lab. Arb. 648 (1965) (Daugherty, Arbitrator) (the provision that changes in the standard work force be "agreed upon in negotiations" was held to preclude the employer's mid-term unilateral reduction in the work force). A requirement of mutual consent also encompasses an interpretation that the contract forecloses the matter from any change since the contract may always be changed with the parties' mutual consent.

63. Samuel M. Gertman Co., 45 Lab. Arb. 30, 33 (1965) (Kennedy, Arbitrator) (the contract cannot be interpreted to disallow the modification if there is full and open bargaining); Hughes Tool Co., 36 Lab. Arb. 1125, $1128-29$ (1960) (Aarron, Arbitrator) (the contract contained a wage reopener for "negotiation," a broad no-strike clause, and an arbitration clause which did not allow addition to or subtraction from the terms of the contract. The arbitrator held that the parties only intended that there be negotiation, and although impasse resulted and the contract forbade a strike, the parties intended that this be the result).

64. See, e.g., Consol, Foods Corp., 47 Lab. Arb. 1162 (1967) (Kelliher, Arbitrator); Cannon Elec. Co., 46 Lab. Arb. 481 (1965) (Kotin, Arbitrator); Western Greyhound Lines, 33 Lab. Arb. 157 (1959) (Kleinsorge, Arbitrator) (the arbitrator determined that the unilateral discontinuation of providing uniforms for drivers was arbitrable since the contract provided for continuance of agreed-upon practices and arbitration disputes of contract interpretation. $\mathrm{He}$ found, however, that the employer had unilateral control over the matter); Cramer Posture Chair Co., 31 Lab. Arb. 283 (1958) (Beatty, Arbitrator).

65. See, e,g., M.K. \& O. Transit Lines, Inc. v. Div. No. 892, 319 F.2d 488, 490 (10th Cir. 1963) (if the union had not terminated the contract, it was evident that the parties had agreed to arbitrate the union demands upon bargaining impasse); Atlanta Newspapers, Inc., 43 Lab. Arb. 758, 761-62 (1964) (King, Arbitrator) (arbitrator found authorization to engage in interest arbitration, but declined to do so); Twin City Rapid Transit Co., 7 Lab. Arb. 845, 848 (1947) (McCoy, Arbitrator) (after determining that the parties wished the arbitration panel to ascertain the terms of the contract, the panel was bound to act as the parties would have reasonably done).

Unions and management in the United States have traditionally shunned "interest arbitration," and less than $2 \%$ of the major collective bargaining agreements provide for any arbitration of terms of a new agreement. A. SMITH, L. Merrifield \& D. RothSChild, Collective BARGAINING \& LABOR ARBITRATION 104 (1970).

66. Ranco, Inc., 50 Lab. Arb. 269, 273 (1968) (Klien, Arbitrator); Pittsburgh-Des Moines Steel Co., 40 Lab. Arb. 577, 581 (1963) (Koven, Arbitrator) (the company made out a credible story that the contract was misdrafted to allow pay for holidays falling on Saturday. The arbitrator held, however, that revision of the contract was beyond his authority since the contract forbade alteration or amendment of the contract); Hughes Tool Co., 36 Lab. Arb. 1125,1128 (1960) (Aarron, Arbitrator) (the arbitrator held that the mandate neither to add to, nor subtract from, the contract's terms precluded establishment of wage rates after a bargaining impasse on reopening. Since the contract only provided for "negotiation" and since arbitration to set rates was uncommon in the industry, not even the presence of a no-strike 
arbitrator should himself determine the merits and content of the proposed change and thus preclude "interest arbitration."

The development of an indigenous system of dispute resolution in industrial relations by means of arbitration gives rise to a potential disparity between, on the one hand, arbitral decisions and, on the other hand, NLRB and judicial positions. For example, with respect to the question of how the parties meant to deal between themselves in relation to the matter to be modified, the arbitrator's decision might be assumed to parallel the Board's decisions holding that either the mutual consent or bargaining provisions of section 8(d) are applicable. However, the cases indicate that the arbitrator will not necessarily use the contractual interpretation standards employed by the Board. Arbitrators tend to weigh more heavily than does the Board the parties' bargaining history and may attempt to determine the true contractual intent of the parties. ${ }^{67} \mathrm{~A}$ more significant difference, however, is the standard which will be used to find that either a waiver of bargaining rights has taken place or that, conversely, mutual consent is required. Failure to interpret collective agreements as requiring the parties to bargain will render arbitrators' standards different from those of the Board since, as has been shown, the Board does not hesitate to interpret bargaining agreements as requiring bargaining to impasse or agreement. ${ }^{68}$ However, the fact that the parties have chosen to bring the dispute within the jurisdiction of an arbitrator may indicate their desire to substitute his judgment for the risk of bargaining to impasse. Arbitration decisions bear out this implicit preference, since looser standards than those used by the Board are employed to find either that one party has unilateral control or that mutual consent is required; those decisions leaving the parties to resolve their differences through bargaining are few..$^{69}$

One line of arbitration cases illustrates a willingness to find unilateral control by one of the parties. In C.G. Bretting Manufacturing Co.. ${ }^{70}$ for example, the employer, without bargaining, transferred

clause in this post-Trilogy arbitration would force the interpretation that there should be arbitration after impasse). On the other hand, in Atlanta Newspapers, Inc., 43 Lab. Arb. 758. 761 (1964) (King, Arbitrator), the arbitrator felt that the absence of the "no addition" clause allowed him the power to add to the contract, although he declined to do so.

67. See Cox, supra note 42, at 1493-1500. See also cases cited supra at note 60.

68. See notes $19-41$ supra and accompanying text.

69. See note 63 supra.

70. 70-1 CCH LAB. ARB. AwARDS If 8167 (1969) (Solomon, Arbitrator). For similar arbitrators' holdings, apparently applying different waiver standards than those indicated by the 
certain employees from one shift to another. The union contended that, although seniority rights as to shifts were not specified in the contract, the parties intended that management would be precluded from altering practices in shift changes without bargaining. Adhering to a residual rights theory, the arbitrator held that the employer retained the right to manage the business except as specifically limited by the collective agreement and determined that management's unilateral action was justified under the contract. Manifestly, the Board would not have reached this result absent clear contractual or bargaining history waiver. ${ }^{71}$ It is therefore apparent that arbitrators $\mathrm{s}^{72}$ can employ standards to interpret the intent of the parties different from those utilized by the Board.

In another line of cases, arbitrators appear to strain in their efforts to find the necessity for mutual consent. ${ }^{73}$ For instance, in Sohio Chemical Co. ${ }^{74}$ the employer approved an exchange of jobs by two employees. When the approval was challenged by the union as a breach of contract, the employer contended that no specific contractual clause was controlling. Without specifically finding a contract violation, the arbitrator determined that the action violated the "spirit" of the agreement and held that mutual consent was required to give the employer power to approve such exchanges. Consequently, a determination was made by the arbitrator consistent with that which would likely be reached by the Board in the same factual situation.

In sum, the introduction of an arbitral solution to a mid-term modification dispute may preclude the necessity of bargaining to impasse and may thereby avoid subsequent initiation of a change in terms and conditions of employment. Since arbitration is viewed as a substitute for bargaining, ${ }^{75}$ the arbitrator will likely employ contract interpretation standards which either allow unilateral control or require mutual consent.

Board and the courts, see Owens-Illinois, Inc., 70-2 CCH LAB. ARB. Awards 0 8606 (1970) (Stouffer, Arbitrator); Lone Star Brewing Co., 53 Lab. Arb. 1317 (1969) (Autrey, Arbitrator); Stewart-IVarner Corp., 33 Lab. Arb. 816 (1960) (Uible, Arbitrator).

71. See notes 26-27 supra and accompanying text.

72. See cases cited supra at note 70 .

73. Sohio Chem. Co., 44 Lab. Arb. 624 (1965) (Witney, Arbitrator); Atlanta Newspapers, Inc., 43 Lab. Arb. 758, 761 (1964) (King, Arbitrator). See also International Shoe Co., 46 Lab. Arb. 752 (1966) (Hilpert, Arbitrator); Yale \& Towne, Inc., 45 Lab. Arb. 923 (1965) (Seidenberg, Arbitrator); United Banking Co., 43 Lab. Arb. 337 (1964) (Kreimer, Arbitrator).

74. 44 Lab. Arb. 624 (1965) (Witney, Arbitrator).

75. See generally Cushman, supra note 43. 


\section{Collyer Insulated Wire: AN EXPANDED ROLE FOR ARBITRATION OF Mid-TERM MODIFICATION DisPUTES}

When mid-term modifications are effected unilaterally by an employer, it is usually after a fait accompli that management's counsel has the opportunity to fit the conduct into some legal rationale. Under these circumstances, problems may arise when an employer, after taking unilateral modifying action, faces an unfair labor practice charge and contends that the union's grievance over the modification is a matter for arbitration rather than for Board proceedings. This is a much litigated situation, ${ }^{76}$ and a recent Board decision ${ }^{77}$ has considerably changed the previously unfavorable position of management in these circumstances.

The employer usually defends against a refusal to bargain charge by claiming contractual authority for his actions. ${ }^{78}$ However, as has been indicated, waiver of bargaining rights requires such specificity that to succeed in this defense an employer must show union acceptance of an appropriate, explicit clause in the collective agreement. The second line of defense is a claim that the arbitration clause requires the union to arbitrate the matter as one involving a dispute related to interpretation of the collective bargaining agreement. Until recently, however, this argument was accepted only in unusual circumstances. ${ }^{79}$

76. See, e.g., 'Consol. Foods Corp., 183 N.L.R.B. No. 78, 74 L.R.R.M. 1374 (1970) (compare majority opinion with concurring opinion); Macy's Calif., 183 N.L.R.B. No. 47, 74 L.R.R.M. 1305 (1970) (compare majority opinion with dissent); Combined Paper Mills, Inc., 174 N.L.R.B. No. 71, 70 L.R.R.M. 1209 (1969); Joseph Schlitz Brewing Co., 175 N.L.R.B. No. 23, 70 L.R.R.M. 1472 (1968); Flintkote Co., 149 N.L.R.B. 1561 (1964); LeRoy Mach. Co., Inc., 147 N.L.R.B. 1431 (1964); Cloverleaf Div. of Adams Dairy Co., 147 N.L.R.B. 1410 (1964); Bemis Bros. Bag Co., 143 N.L.R.B. 1311 (1963).

77. Collyer Insulated Wire, 192 N.L.R.B. No. 150, 77 L.R.R.M. 1931 (1971),

78. See, e.g., Unit Drop Forge, Div., Eaton Yale \& Towne, 171 N.L.R.B. No. 73, 68 L.R.R.M. 1129 (1968); Scam Inst. Corp., 163 N.L.R.B. 284, 287 (1967), enforced, 394 F.2d 884 (7th Cir.), cert. denied 393 U.S. 980 (I968); C \& C Plywood Corp., I48 N.L.R.B. 414 (1964); LeRoy Mach. Co., Inc., 147 N.L.R.B. 1431 (1964).

79. Flintkote Co., 149 N.L.R.B. I561, 1562 (1964); Bemis Bros. Bag Co., 143 N.L.R.B. 1311, 1312 (1963); Montgomery Ward \& Co., 137 N.L.R.B. 418,423 (1962). NLRB General Counsel Nash stated that the Board's pre-Collyer position was to defer in cases where there had been or would be actual resort to the arbitral process as distinguished from failure to voluntarily resort thereto when the process was available. Address by General Counsel Nash, FMCS-AAA Regional Conference on Labor Arbitration, Buffalo, N.Y., October 15, 1971, reported in 78 BNA LAB. REL. REP. 159 (197I). The prc-Collyer position is illustrated by two Board decisions. In Joseph Schlitz Brewing Co., 175 N.L.R.B. No. 23, 70 L.R.R.M. 1472 (1968), the employer, with substantial contractual authority, unilaterally discontinued providing a "relief man" to operate equipment while "regulars" were on break. Rather than passing 
However, the Board recently reversed its previous consistent reluctance to defer to arbitration in circumstances involving an unfair labor practice charge and, in Collyer Insulated Wire ${ }^{80}$ held that under certain circumstances it would defer to arbitration of a matter which was alleged to be both a breach of contract and an unfair labor practice. ${ }^{81}$ In Collyer, the employer unilaterally granted skilled maintenance personnel wage increases, an action which arguably was permissible under the terms of the collective agreement. The union claimed that the unilateral action was not contractually authorized since the employer had attempted to obtain these changes during contract negotiations, but had been refused by the union unless plantwide wage hikes were granted. The Board held that the matter could be resolved by contract interpretation pursuant to the bargained-for settlement procedures, even though the action constituted a possible refusal to bargain in violation of section $8(a)(5) .{ }^{82}$ The Board found that "this dispute in its entirety arises from the contract between the parties and from the parties' relationship under the contract . . . ." Since "the parties have contractually committed themselves to mutually agreeable procedures for resolving their disputes" and because these procedures "made available a quick and fair means for the resolution of this dispute," tion.

on the union's unfair labor practice charge, the Board deferred to arbitration since the employer had not taken the action to undermine the union and had acted with substantial contractual justification. Further, the Board noted that the arbitration clause appeared to encompass the dispute and would allow solution in accordance with the Act.

The more typical Board reaction to an employer's invocation of the arbitration clause after effecting a mid-term modification is illustrated by Cloverleaf Div. of Adams Dairy Co., 147 N.L.R.B. 1410 (1964). In Cloverleaf, the employer unilaterally reassigned customers of its driver-salesmen, thereby effecting an admitted change in conditions of employment contained in the contract. The Board rejected the employer's defense that the union was required to resort to hinding arbitration and held that, even if the matter were arbitrable, the employer had clearly committed a section $8(\mathrm{a})(5)$ violation by acting unilaterally with respect to a mandatory subject of bargaining rights. Id. at 1415 . Cloverleaf illustrates two important points: first, action before eithcr bargaining or arbitration constitutes a section $8(a)(5)$ refusal to bargain unless bargaining rights have been waived; second, action followed by invocation of arbitration does not fulfill the cmployer's statutory duty to bargain.

80. 192 N.L.R.B. No. 150, 77 L.R.R.M. 1931 (1971).

81. Id., 77 L.R.R.M. at 1936. For a considerably more informal analysis of the anticipated impact of Collyer on the adjudication of disputes, see Address of NLRB Chairman E.B. Miller, Conference of Western States Employers Ass'n Executives, Pebble Beach, Cal., Aug. 27, 1971, reported in 78 BNA LAB. REL. REP. 28 (1971).

82. 77 L.R.R.M. at 1935-38.

83. Id. at 1934.

84. Id. at 1937 .

85. Id. at 1934 . 
The impact of Collyer upon mid-term modifications is farreaching. The decision indicates that whenever the desired mid-term modification is based upon contractual authority which clearly raises an arbitrable issue of contract interpretation, ${ }^{86}$ the Board will be amenable to deferral even though unilateral action, possibly in violation of section 8(a)(5), has already occurred.

The advantages of the decision are quite obvious. If the parties had intended that a matter be submitted to arbitration, initiation of an unfair labor practice charge by one party only prolongs the dispute. Moreover, even after deciding that an unfair labor practice has been committed, the Board will usually only order the employer to rescind the unilateral action and to bargain before proceeding further ${ }^{87}$ Thus, the matter will still be remanded to carry out the arbitration or bargaining processes which perhaps already would have resolved the parties' dispute.

On the other hand, submission of the matter to an arbitrator may not always fulfill the purposes of the Act as interpreted by the Board. In theory, the arbitrator is bound by the collective agreement, rather than by the Act and interpretive case law. Thus, without applying the same rigid standards governing waiver used by the Board, the arbitrator may well find that the union waived its right to bargain on a matter. As previously discussed, ${ }^{88}$ in order to preclude the dangers of mid-term bargaining to impasse, the arbitrator may strain to find either contractual authority for bargaining waiver, and consequent unilateral control, or the requirement for mutual consent before change.

As the Board has made clear, and as the NLRB General Counsel has also pointed out ${ }^{89}$ there are effective qualifications on the "Collyerability" ${ }^{90}$ of unilateral action which is both arbitrable and a possible unfair labor practice: the contractual basis for the action must have been substantial; the arbitral procedure must be adequate to resolve the unfair labor practice charge and contract interpretation dispute in consonance with the Act; there must be evidence of a relationship between the parties conducive to arbitral resolution of

86. The Board emphasizes that the dispute must be over a good-faith contract intcrpretation-"the vcry stuff of labor contract arbitration." Id. at 1936-37.

87. See cases cited supra at note 18.

88. Sce notes 68-74 supra and accompanying text.

89. Address of General Counsel Nash, supra note 79, at 161.

90. Id. at 165 . 
problems; ${ }^{91}$ the procedures must conform to standards established by the Board in Spielberg $M f g$. Co. ${ }^{92}$ and the Board will retain jurisdiction for the limited purpose of entertaining a motion from a party complaining that the purposes of the Act have been offended by the arbitration. ${ }^{93}$

Despite these assurances, however, unless the Board closely polices the standards by which arbitrators allow bargaining waivers, there will likely be both a Board standard and arbitrators' standards for the allowance of unilateral mid-term modification..$^{94}$ Since the parties have agreed to submit their grievances to binding arbitration, a double standard or possible departure from the statutory standard may be justified by the benefits of industrial self-government. Nevertheless, as the dissent in Collyer points out, the parties are henceforth precluded from exercising the previously available choice between the strict statutory/case-law bargaining waiver standards and the less predictable arbitration standards. ${ }^{95}$ Furthermore, by allowing management to take action prior to arbitration, Collyer contravenes a definite policy against unilateral action. ${ }^{96}$ Realizing this, an employer may be likely to proceed in cases where an argument of contractual justification for the unilateral action can reasonably be made. Although the standards stated by the Board for the use of Collyer assume good faith use of the arbitral process, ${ }^{97}$ there may be a tendency to allow the class of "Collyerable" cases to expand in order to ease the Board's caseload pressure. ${ }^{98}$

Thus, when a union challenges an employer's right to make unilateral changes, the employer will not be subject to the threat of an unfair labor practice charge if he is willing to arbitrate the matter. Oddly enough, while the trend of Board and court decisions has

91. 77 L.R.R.M. at 1936.

92. $I d$. at 1937 .

[T] he proceedings appear to have been fair and regular, all parties had agreed to be bound, and the decision of the arbitration panel is not clearly repugnant to the purposes and policies of the Act. Spielberg Mfg. Co., 112 N.L.R.B. 1080, 1082 (1955).

93. 77 L.R.R.M. at 1938.

94. See notes 68-74 supra and accompanying text.

95. 77 L.R.R.M. at 1940-44.

96. See notes 7-10 supra and accompanying text.

97. 77 L.R.R.M. at 1936.

98. Address of Chairman Miller, supra note 81. Chairman Miller points to the caseload backlog as one of the major problems plaguing the national labor policy and discusses Collyer as a possible mcans of shifting the burden of labor regulation from the Board to industrial selfgovernment. 
required either bargaining before action or drafting specific clauses to meet anticipated need, the Collyer approach may encourage parties to act first and await possible reaction.

\section{SUMmaRY}

Action without prior consultation with the other party-by either bargaining or arbitration-is rarely proper under the Act. Nonetheless, absent contradictory contractual provisions and modifications affecting a term of employment contained in the contract, the legal ability of the employer to make mid-term modifications after bargaining to impasse clearly exists. The effect of arbitration clauses on this ability is highly significant. On the one hand, these provisions can be a hindrance, since the arbitrator may find that either the modification was intended by the parties to be accomplished with mutual consent or that he must decide on the content of the modification. However, in view of possible adverse union reaction to unilateral action after impasse,$^{99}$ the employer may be well-advised to resort to the arbitrator rather than incur his employees' wrath by effecting a modification of working conditions during the term of a contract. The new development reflected by Collyer quite possibly gives the employer more latitude by allowing him to make the change first and arbitrate later if the union objects. While Collyer subjects management's new latitude to the Board's ultimate review of the arbitral decision, the precise boundaries of this limitation are not yet clear.

99. See note 58 supra. 